\title{
Pendampingan Pembuatan Zat Pengatur Tumbuh (ZPT) pada Kelompok Tani Palem Desa Sumedangan Kabupaten Pamekasan Madura
}

\author{
(Assistance for the Making of Growth Regulating Substances (ZPT) in Sumedangan \\ Village Palm Farmers Group) \\ Iswahyudi $^{1^{*}}$, Shefa Dwijayanti Ramadani ${ }^{2}$, Agus Budiyono $^{3}$ \\ ${ }^{1}$ Agroteknologi, Faperta, Universitas Islam Madura-JL.PP.Miftahul Ulum Bettet Pamekasan \\ ${ }^{2}$ Pendidikan Biologi, FKIP, Universitas Islam Madura-JL.PP.Miftahul Ulum Bettet Pamekasan \\ ${ }^{3}$ Pendidikan Fisika, FKIP, Universitas Islam Madura-JL.PP.Miftahul Ulum Bettet Pamekasan
}

\section{ARTICLE INFO}

Article history

Received : 28 October 2020

Revised : 21 November 2020

Accepted : 24 November 2020

DOI :

http://dx.doi.org/10.33366/jast.v4i2.1692

\section{Keywords}

bamboo shoot

growth regulatory substance;

rice

*e-mail corresponding author : iswahyudi@uim.ac.id

\section{(c) (7) (2)}

This is an open access article under the Creative Commons Attribution-ShareAlike 4.0 International License. Any further distribution of this work must maintain attribution to the author(s) and the title of the work, journal citation and DOI. CC-BY-SA

\section{ABSTRACT}

Every plant has a small amount of natural growth hormone. However, under certain conditions, plants cannot produce enough hormones, so growth regulators or additional hormones are needed. Plant Growth Regulators (PGRs) have become an essential component in agriculture to facilitate plant growth. Unfortunately, the "Palem" Farmer Group in Sumedangan Village does not have enough understanding and ability to make plant growth regulators. This community service aimed to provide training and assistance to the "Palem" Farmer Group to produce and apply PGRs on plants. The service methods used were initiated by socialization through Focus Group Discussion (FGD), followed by training assistance and PGRs application assistance in the field. The result of technology dissemination in the area showed a positive response indicated by the "Palem" Farmer group's enthusiastic response while making PGRs using bamboo shoots and coconut water. The evaluation and monitoring results also showed an increase in four parameters of the participants' abilities, including knowledge (70.07\%), attitudes $(60 \%)$, skills $(84.44 \%)$, and the results of pretest/posttest $(83.33 \%)$ on the application of ZPT on plants.

\section{PENDAHULUAN}

Desa Sumedangan yang berada di Kabupaten Pamekasan merupakan salah satu desa sentra produksi tanaman pangan. Desa ini mempunyai jumlah penduduk sebanyak 3.203 orang. Masyarakat di desa tersebut umumnya memiliki mata pencaharian di bidang pertanian dan peternakan [1]. Di bidang pertanian, Desa Sumedangan memiliki sekitar 216 hektar lahan yang terbagi menjadi 118 hektar lahan sawah dan 98 hektar lahan bukan sawah. Sekitar 0,5 hektar dari luasan sawah tersebut dikelola oleh suatu kelompok Tani yang dikenal sebagai Kelompok Tani "Palem”. 
Kelompok Tani Palem memiliki kepedulian terhadap keadaan lahan yang terus menurun akibat pemupukan kimia yang berlebihan. Kelompok Tani ini berkeinginan untuk mengembalikan kualitas lahan menjadi lahan yang bebas pupuk sintetis, serta mampu menghasilkan pangan semi organik bahkan pangan organik secara berkesinambungan melalui penerapan pertanian organik. Sayangnya, petani menghadapi masalah utama berupa menurunnya mjutu lahan akibat penggunaan pupuk sintetis yang berlebihan. Hal tersebut sejalan dengan penjelasan Suyamto bahwa pemberian dosis pupuk kimia secara berlebihan berdampak terhadap degradasi struktur tanah, penipisan unsur hara mikro dan makro, serta terganggunya kehidupan mikroba dalam tanah [2].

Kondisi semacam itu menjadi alasan bagi petani untuk segera melakukan perbaikan kualitas lahan dengan mengembalikan kemampuan lahan secara alamiah menggunakan Zat Pengatur Tumbuh (ZPT), sehingga dapat meningkatkan pertumbuhan tanaman dan efisiensi pengolahan tanah. Kesadaran kelompok Tani Palem dalam upaya mengembalikan kesuburan alamiah lahan dengan memanfaatkan ZPT organik menjadikan keberadaan Tani Palem penting untuk diperhatikan. Dalam jangka panjang, kelompok ini juga berpotensi untuk bisa diandalkan sebagai penyedia produk pertanian yang sehat sekaligus ramah lingkungan.

ZPT adalah senyawa yang mutlak diperlukan tanaman karena berperan dalam mendukung pertumbuhan tanaman sekalipun ketersediaan unsur hara mencukupi [3]. Oleh karenanya, ZPT merupakan senyawa organik yang tidak termasuk unsur hara, namun diperlukan untuk mempengaruhi proses fisiologis dari tanaman [4]. Tanaman sebetulnya dapat menghasilkan ZPT secara alami, namun seringkali jumlah yang dihasilkan tidak cukup optimal, sehingga diperlukan ZPT tambahan untuk menghasilkan respon pertumbuhan yang maksimal.

ZPT eksogen dapat diperoleh baik secara sintetik maupun alami. ZPT sintetis umumnya belum banyak digunakan oleh petani, sementara ZPT alami merupakan ZPT alternatif yang tersedia di alam dan berasal dari bahan-bahan organik. [5]. Oleh karenanya, ZPT alami memiliki lebih banyak kelebihan diantaranya yaitu lebih ramah lingkungan, mudah diperoleh, lebih aman digunakan, dan relatif lebih murah. Sejumlah bahan yang dapat digunakan sebagai penyusun ZPT alami misalnya adalah air kelapa, urin sapi, maupun ekstraksi dari bagian tumbuhan seperti kecambah kacang hijau (touge), bawang merah, rebung bambu, maupun bonggol pisang, dan lain-lain. Sejumlah bahan alami tersebut merupakan sumber dari berbagai macam hormon pertumbuhan seperti auksin, giberelin, dan sitokinin $[3,5,6]$.

Berdasarkan uraian di atas, maka ZPT alami sangat mungkin untuk digunakan petani dalam rangka mengoptimalkan pertumbuhan dan produksi tanaman, sekaligus menjaga keseimbangan lingkungan. Namun demikian, kelompok Tani Palem rupanya mengalami kendala dalam memproduksi maupun mengaplikasikan ZPT di lapang.

\section{Permasalahan Mitra:}

Berdasarkan hasil diskusi di lapangan, terdapat setidaknya dua kendala 
yang dihadapi oleh kelompok Tani Palem di Desa Sumedangan yaitu: (a) para petani belum menguasai teknologi produksi ZPT dan (b) para petani belum menguasai cara aplikasi ZPT di lapang. Oleh karenanya, untuk mengatasi permasalahan yang dihadapi mitra, maka kelompok Tani Palem yang berada di Desa Sumedangan ini perlu diberikan dorongan, pendidikan masyarakat, pelatihan, dan pendampingan dalam memproduksi dan mengaplikasikan ZPT di lapangan.

\section{METODE KEGIATAN}

Metode kegiatan pengabdian masyarakat yang diberikan untuk menyelesaikan permasalahan mitra meliputi: (1) pendidikan masyarakat tentang ZPT sebagai salah satu metode/usaha mempercepat pertumbuhan tanaman, sekaligus pengetahuan tentang berbagai jenis ZPT, (2) pelatihan pembuatan ZPT, dan (3) pendampingan aplikasi ZPT hasil pelatihan di lapang. Pada tahap pelatihan, digunakan metode ToT/ Training of Trainer sebanyak dua kali. ToT-1 diikuti oleh dua peserta perwakilan kelompok Tani Palem, sementara ToT-2 diikuti oleh 25 peserta kelompok Tani Palem.

Bahan baku produksi ZPT yang digunakan yaitu terdiri atas: (1) rebung bambu, (2) tetes tebu, (3) air rendaman dedak, dan (4) air kelapa.

\section{KARYA UTAMA}

\subsection{Pendidikan Masyarakat}

Dalam pelaksanaan pendidikan masyarakat, kelompok tani diberikan pemahaman tentang macam-macam ZPT. Tujuan dari kegiatan tersebut adalah berfokus untuk memberikan informasi pada petani mengenai macam-macam ZPT dan manfaatnya. Dengan demikian, para petani dapat dengan tepat memberikan ZPT pada tanaman sesuai kebutuhannya.

\subsection{Pelatihan pembuatan ZPT}

Pembuatan ZPT sebanyak 20 liter membutuhkan wadah jerigen berkapasitas 20 liter dengan menggunakan bahan baku yaitu: (1) $6 \mathrm{~kg}$ rebung bambu, (2) 1 liter tetes tebu, (3) $1 \mathrm{~kg}$ dedak, dan 4) 2 liter air kelapa.

Adapun proses pembuatan ZPT yaitu diuraikan sebagai berikut. Rebung bambu yang diperoleh dari sekitar rumah petani dibersihkan dan dicuci bersih. Kemudian rebung dihancurkan dengan cara diblender hingga halus. Sementara itu, sebanyak 1 liter tetes tebu diencerkan dengan sebanyak 2 liter air agar mudah dicampur dengan bahan lainnya. Demikian pula sebanyak $1 \mathrm{~kg}$ dedak dilarutkan dengan sebanyak 3 liter air, kemudian disaring untuk memisahkan bagian ampas dan air. Air dedak selanjutnya digunakan untuk campuran pembuatan ZPT, sementara bagian ampas dedak dibuang.

Pada proses berikutnya, seluruh bahan pembuatan ZPT dimasukkan ke dalam wadah jerigen, ditambahkan sebanyak 2 liter air kelapa dan air hingga mencapai 20 liter. Jerigen selanjutnya ditutup rapat selama proses fermentasi. Proses fermentasi ini membutuhkan waktu kurang lebih 14 hari. Namun sebelumnya, tutup jerigen tersebut diberi lubang yang tersambung dengan selang yang mengarah pada air. Hal ini dilakukan supaya udara yang berasal dari hasil fermentasi dapat keluar, tetapi sebaliknya udara yang berasal dari luar tidak akan masuk ke 
dalam wadah. Pelaksanaan pelatihan pembuatan ZPT dapat dilihat pada Gambar 1.

\subsection{Pendampingan Aplikasi ZPT ke Tanaman}

Aplikasi ZPT pada tanaman dilakukan melalui pengenceran larutan ZPT sebanyak $250 \mathrm{ml}$ dengan air sebanyak 14-17 liter. ZPT selanjutnya disemprotkan pada tanah di sekitar pangkal batang tanaman sehingga dapat segera masuk ke dalam rhizosfer tanaman. Dengan demikian, ZPT dapat segera beradaptasi dan berasosiasi dengan akar tanaman.

Pada kegiatan ini, aplikasi ZPT dilakukan pada benih padi. Pada tahap ini, digunakan pula pupuk kimia sebesar 50\% dari jumlah yang biasa digunakan oleh petani. Agar aplikasi ZPT lebih mudah dipahami oleh petani, tim pelaksana memberikan contoh cara aplikasi untuk selanjutnya diikuti oleh petani.

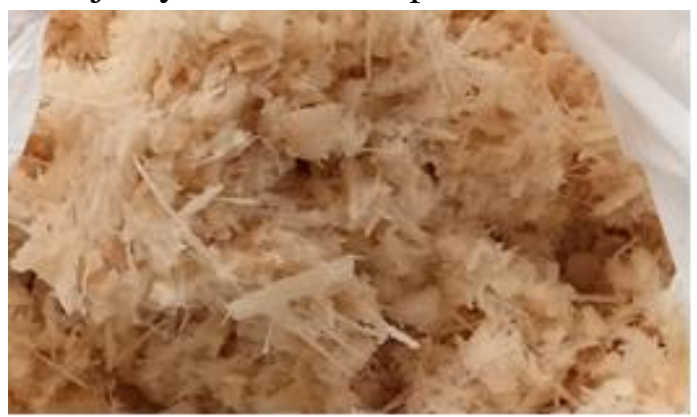

A

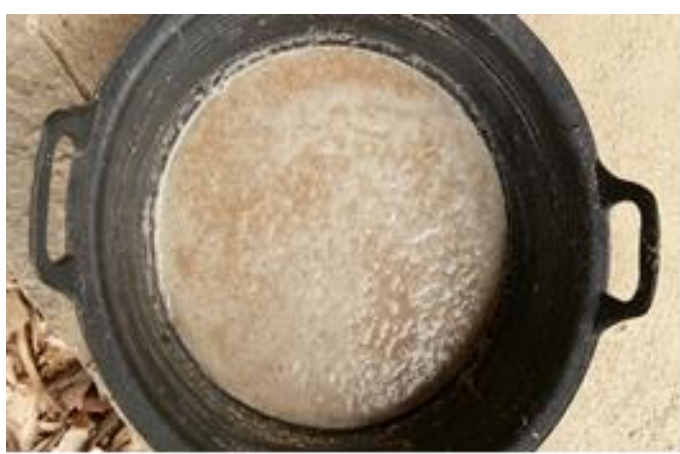

B

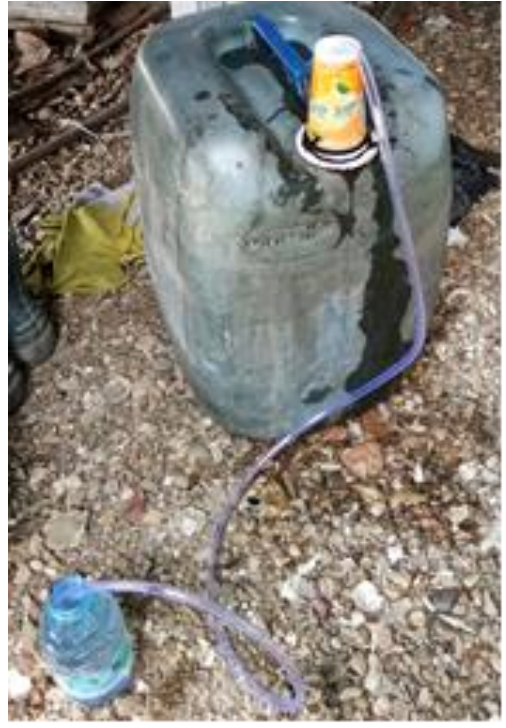

C

Gambar 1. Pelatihan pembuatan ZPT.

(A) Rebung bambu halus, (B) Rendaman dedak, (C) Pemasangan selang pada tutup jerigen.

\section{ULASAN KARYA}

Pelaksanaan pendidikan masyarakat pembuatan ZPT dilaksanakan pada mitra yaitu Kelompok Tani Palem Desa Sumedangan. Mitra yang mengikuti pelatihan sebanyak 17 orang dari 25 orang total anggota kelompok mitra.

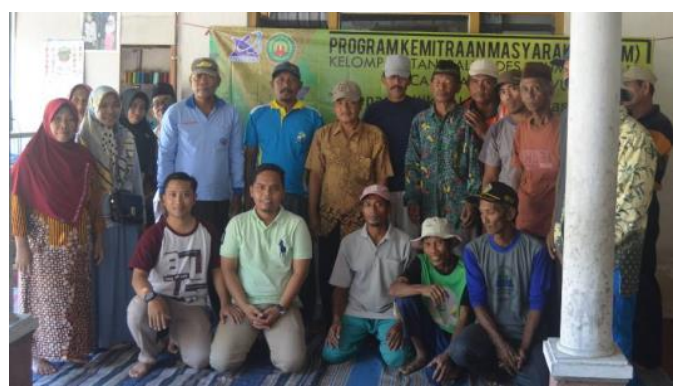

Gambar 2. Profil Kelompok Tani Palem

Zat Pengatur Tumbuh (ZPT) merupakan senyawa organik bukan hara yang diperlukan untuk mempengaruhi proses biologi dalam jaringan tanaman [7], sehingga menjadi komponen penting dalam bidang pertanian untuk mengoptimalkan pertumbuhan tanaman. 
Perannya antara lain meningkatkan, menghambat, atau secara kualitatif merubah pertumbuhan dan perkembangan tanaman. ZPT juga dipakai secara luas untuk menstimulasi pertumbuhan, mendorong pematangan buah, serta merangsang perbungaan pada tanaman holtikultura [8]. Meskipun demikian, kinerja dari setiap ZPT bergantung dari tipe, struktur kimia, konsentrasi, genotipe tanaman, serta fase fisiologi tanaman [9].

Terdapat enam golongan ZPT yang terkenal dalam dunia pertanian, yaitu Auksin, Giberelin, Sitokinin, Asam Absisik, Retardan, dan Etilen. Dua dari keenam hormon tersebut, yaitu auksin dan giberelin lazim dijumpai pada ZPT alami. Hormon auksin berpran dalam merangsang pembelahan sel, sintesis DNA kromosom, dan pertumbuhan aksis longitudinal tanaman. Dengan kata lain, untuk menumbuhkan akar dan pucuk tanaman dapat digunakan hormon ini, sehingga akar dapat lebih cepat tumbuh. Selain itu, hormon giberelin berfungsi sebagai pengontrol pertumbuhan pada seluruh bagian tanaman, termasuk merangsang proses perkecambahan. Sebagian besar giberelin juga berpengaruh terhadap pertumbuhan batang tanaman [10].

ZPT alami yang diproduksi dan diaplikasikan dalam program pelatihan ini mengandung hormon giberelin yang berasal dari rebung bambu, serta air kelapa sebagai sumber sitokinin. Giberelin berpengaruh terhadap pembesaran tanaman, karena dapat memicu pembelahan dan pertumbuhan sel yang mengarah pada pemanjangan batang dan perkembangan daun, sehingga laju fotosintesis meningkat dan meningkatkan keseluruhan pertumbuhan, termasuk akar [11]. Giberelin juga berperan dalam proses perkecambahan, utamanya dalam memecah dormansi. Meskipun giberelin secara alami terdapat dalam biji, namun penambahan giberelin eksogen tetap diperlukan untuk mencegah kekurangan giberelin pada biji yang dikecambahkan [3]. Demikian pula, sitokinin yang terdapat dalam aplikasi ZPT berperan dalam pembelahan sel. Mukminin et al. mengungkapkan bahwa sitokinin yang terkandung dalam air kelapa muda dapat merangsang pertumbuhan tunas serta mengaktifkan kegiatan sel-sel hidup [12]. Selain itu, sitokin bersama dengan giberelin juga berperan dalam peristiwa dormansi biji [3].

Potensi penggunaan ZPT berbahan dasar rebung bambu maupun air kelapa muda telah dilaporkan oleh sejumlah peneliti. Mardalini dan Sutriana memperlihatkan bahwa pemberian ekstrak rebung 4,5ml/L air menunjukkan pengaruh baik terhadap tinggi dan bobot tanaman kacang hijau [13]. Penambahan ekstrak rebung bambu pada semaian sengon juga efektif untuk meningkatkan pertumbuhan bibit sengon pada dosis 20 $\mathrm{ml} /$ bibit sampai $50 \mathrm{ml} /$ bibit [14]. Sementara itu, hasil pengabdian lainnya mengungkapkan bahwa pengunaan ZPT alami secara nyata mampu meningkatkan jumlah daun, luas daun dan lebar batang pruning pohon gaharu [15].

ZPT eksogen yang ditambahkan pada media akan berinteraksi dengan ZPT endogen selama proses pembentukan organ, misalnya saat pembentukan tunas atau akar tanaman [16]. Dalam hal ini, penambahan giberelin serta sitokinin ke dalam media kultur dapat meningkatkan 
konsentrasi zat pengatur tumbuh endogen di dalam sel, sehingga menjadi "faktor pemicu" dalam proses tumbuh dan perkembangan jaringan.

Tahap pertama dalam program pengabdian masyarakat ini yaitu pendidikan masyarakat mengenai ZPT kepada kelompok Tani Palem menunjukkan respon yang positif dari para peserta. Pada kesempatan ini, para peserta menunjukkan sikap antusias serta tidak ragu untuk menyampaikan pertanyaan mengenai hal yang belum dipahami. Perubahan paling mendasar yang nampak setelah proses pendidikan masyarakat dilakukan yaitu berubahnya paradigma para petani dalam upaya meningkatkan pertumbuhan tanaman secara optimal dengan bahan yang mudah diperoleh, mudah dibuat, dan mudah diaplikasikan, sekaligus bersifat ramah terhadap lingkungan.

Untuk memperoleh informasi secara pasti mengenai hasil pendidikan masyarakat, dilakukan pula pengukuran terhadap empat parameter kemampuan peserta yang meliputi knowledge, attitude, skill dan hasil pretest/posttest. Hasil pengukuran tersebut menunjukkan bahwa terjadi peningkatan terhadap keempat parameter yang diukur pada diri mitra (Gambar 3).

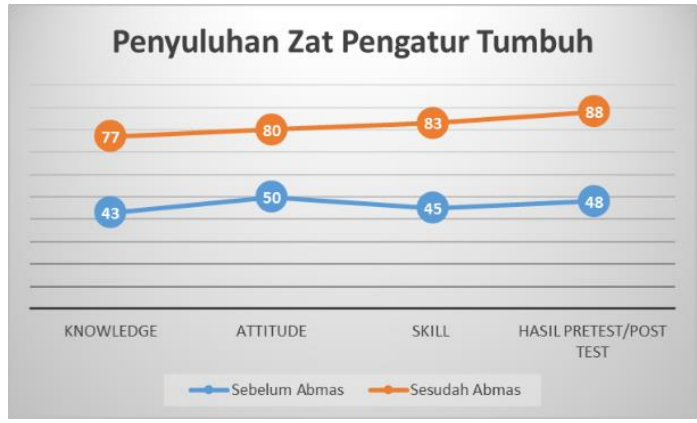

Gambar 3. Grafik pengukuran kemampuan peserta saat pendidikan masyarakat (penyuluhan) macam-macam ZPT
Pada tahap selanjutnya yaitu pelatihan pembuatan ZPT, mitra dibekali keterampilan dalam memproduksi ZPT alami menggunakan campuran rebung bambu, tetes tebu, dedak, dan air kelapa muda. Metode pembuatan ZPT ini cukup sederhana sehingga dapat dipahami dan dipraktekkan dengan mudah oleh mitra.

Pada tahap terakhir yaitu pendampingan aplikasi ZPT pada tanaman, tim pengabdian masyarakat memperikan contoh cara aplikasi ZPT pada tanaman, kemudian diikuti dengan mitra. Dengan demikian, para peserta dapat dengan lebih mudah memahami cara aplikasi ZPT dengan tepat.

Selanjutnya untuk mengetahui keberhasilan program pengabdian masyarakat yang telah dilakukan, dilakukan evaluasi terhadap empat parameter dari kemampuan mitra di akhir kegiatan, yang meliputi knowledge, attitude, skill dan hasil pretest/posttest pada pengaplikasian ZPT. Hasilnya yaitu terjadi peningkatan yang positif terhadap keempat parameter yang diukur (Gambar 3). Besarnya peningkatan pada aspek knowledge yaitu sebesar $79.07 \%$, aspek attitude sebesar $60 \%$, aspek skills sebesar $84.44 \%$, dan peningkatan hasil pretest/posttest sebesar $83.33 \%$. Dengan kata lain, rerata peningkatan untuk seluruh aspek yang diukur yaitu sebesar $76,71 \%$. Hal ini mengindikasian bahwa tingkat keberhasilan dari program yang telah dilaksanakan cukup tinggi. Dengan demikian, melalui program pengabdian masyarakat ini mitra menjadi lebih sadar akan pentingnya pemberian ZPT pada tumbuhan, sekaligus memiliki keterampilan dalam memproduksi dan mengaplikasikannya pada tanaman. 
Terlebih lagi, ZPT yang dibuat berasal dari bahan alami yang mudah diperoleh, mudah dibuat, serta berdampak baik bagi lingkungan.

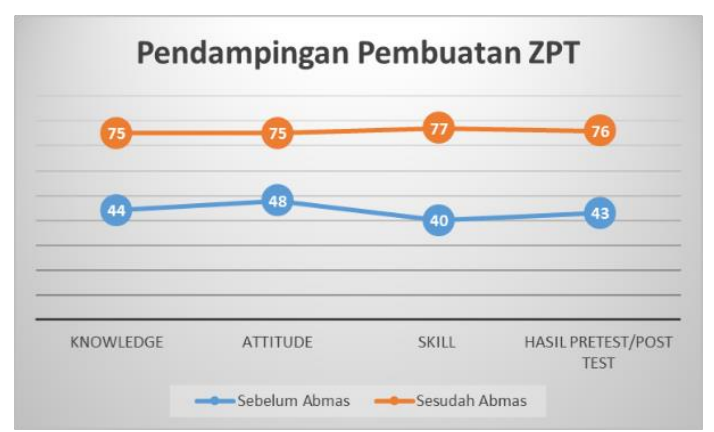

Gambar 4. Grafik pendampingan pembuatan ZPT

\section{DAMPAK DAN MANFAAT KEGIATAN}

ZPT adalah senyawa organik bukan hara yang pada konsentrasi rendah dapat mendorong, menghambat, atau secara kualitatif merubah pertumbuhan dan perkembangan tanaman. Ada dua tipe ZPT yang diaplikasikan pada tanaman yaitu yang bersifat alami dan sintetis. Pada kegiatan ini, diberikan pendidikan masyarakat, pelatihan, dan pendampingan aplikasi ZPT organik yang berasal dari campuran rebung bambu dan air kelapa muda.

Upaya diseminasi teknologi melalui kegiatan pengabdian masyarakat ini memperoleh respon yang sangat baik dari kelompok tani. Hal ini terbukti dari antusiasme peserta saat mengajukan pertanyaan mengenai manfaat dan cara penggunaan teknologi ZPT. Selain itu, banyak petani yang kemudian semakin termotivasi untuk bisa memproduksi dan menggunakan ZPT setelah mengetahui bahwa aplikasi bahan tersebut menunjukkan hasil yang lebih baik pada tanaman yang telah diuji cobakan.

\section{KESIMPULAN}

Berdasarkan hasil pendampingan pembuatan Zat Pengatur Tumbuh (ZPT) pada Kelompok Tani Palem di Desa Sumedangan, dapat ditarik kesimpulan sebagai berikut.

1) Kelompok Tani Palem sangat antusias dalam pembuatan ZPT berbahan rebung bambu dan air kelapa.

2) Terjadi peningkatan empat parameter kemampuan peserta yaitu knowledge (79.07\%), attitude (60\%), skill $(84.44 \%)$, dan hasil pretest/posttest $(83.33 \%)$ pada pengaplikasian ZPT pada tanaman.

\section{PENGHARGAAN}

Terimakasih disampaikan kepada Universitas Islam Madura yang telah mendanai kegiatan ini melalui hibah Program Kemitraan Masyarakat (PKM) tahun anggaran 2020.

\section{DAFTAR PUSTAKA}

[1] B. P. S. K. Pamekasan, "Kecamatan Pademawu Dalam Angka 2019," S. IPDS, Ed.: BPS Kabupaten Pamekasan, 2019.

[2] S. Suyamto, "Manfaat Bahan dan Pupuk Organik pada Tanaman Padi di Lahan Sawah Irigasi," Iptek Tanaman Pangan, vol. 12, no. 2, 2017.

[3] F. Kurniati, T. Sudartini, and D. Hidayat, "Aplikasi berbagai bahan ZPT alami untuk meningkatkan pertumbuhan bibit kemiri sunan (Reutealis trisperma (Blanco) Airy Shaw)," Jurnal Agro, vol. 4, no. 1, pp. 40-49, 2017.

[4] Y. Nurlaeni and M. I. Surya, "Respon stek pucuk Camelia japonica terhadap pemberian Zat Pengatur Tumbuh organik," in Prosiding Seminar Nasional Masyarakat Biodiversifikasi 
Indonesia, 2015, vol. 1, no. 5, pp. 1211-1215.

[5] Y. Zhao, "Auxin biosynthesis and its role in plant development," Annual review of plant biology, vol. 61, pp. 49-64, 2010.

[6] N. Nazir, M. Sharma, and A. Khalil, "Effect of exogenous application of plant growth regulators on vine growth, yield and quality attributes in kiwifruit cv. Hayward," The Horticultural Society of India (Regd.), vol. 75, no. 1, pp. 153-156, 2018.

[7] T. Gaspar et al., "Changing concepts in plant hormone action," In Vitro Cellular \& Developmental BiologyPlant, vol. 39, no. 2, p. 85, 2003.

[8] S. Strydhorst, L. Hall, and L. Perrott, "Plant growth regulators: What agronomists need to know," Crops and Soils, vol. 51, no. 6, pp. 22-26, 2018.

[9] V. Satyavathi, P. Jauhar, E. Elias, and M. Rao, "Effects of growth regulators on in vitro plant regeneration in durum wheat," Crop Science, vol. 44, no. 5, pp. 1839-1846, 2004.

[10]A. Nizar, "Pengaruh Penggunaan Rebung Bambu Sebagai Zat Pengatur Tumbuh Terhadap Pertumbuhan Dan Produksi Bawang Merah (Allium Ascolonicum L) Varietas Lokal Bauji," AGRIEKSTENSIA, vol. 17, no. 2, pp. 92-98, 2018.

[11] M. Arif, M. Murniati, and A. Ardian, "Uji Beberapa Zat Pengatur Tumbuh Alami Terhadap Pertumbuhan Bibit Karet (Hevea Brasiliensis Muell Arg) Stum Mata Tidur," Jurnal Online Mahasiswa Fakultas Pertanian
Universitas Riau, vol. 3, no. 1, pp. 110, 2016.

[12] L. H. Mukminin, P. M. A. Asna, and F. K. Setiowati, "Pengaruh Pemberian Giberelin (GA3) dan Air Kelapa Terhadap Perkecambahan biji Anggrek Bulan (Phalaenopsis sp.) Secara In Vitro," 2016.

[13]M. Mardaleni and S. Sutriana, "PEMBERIAN EKSTRAK REBUNG DAN PUPUK HORMON TANAMAN UNGGUL TERHADAP PERTUMBUHAN DAN PRODUKSI KACANG HIJAU (Vigna radiata $\mathrm{L}$ )," DINAMIKA PERTANIAN, vol. 29, no. 1, pp. 45-56, 2017.

[14] S. Sudarso, N. Nelvia, and M. A. Khoiri, "Pemberian Zat Pengatur Tumbuh (Zpt) Alami Pada Bibit Kelapa Sawit (Elaeis Guineensis Jacq) Di Main-nursery," Jurnal Online Mahasiswa Fakultas Pertanian Universitas Riau, vol. 2, no. 2, pp. 1-7, 2015.

[15] I. G. A. S. Wangiyana and D. S. Putri, "Aplikasi Zat Pengatur Tumbuh dan Kegiatan Pruning dalam Optimalisasi Budidaya Gaharu di Desa Duman Kecamatan Lingsar Lombok Barat," Lumbung Inovasi: Jurnal Pengabdian kepada Masyarakat, vol. 4, no. 1, pp. 54-62, 2019.

[16] I. D. P. S. Hendaryono, M. Si, and I. A. Wijayani, Teknik kultur jaringan, pengenalan dan petunjuk perbanyakan tanaman secara vegetatif-modern. Kanisius, 1994. 